\title{
Konceptualizace pojmů rasa a rasismus: Sociologický pohled
}

\author{
Conceptualizing Race and Racism: A Sociological Perspective \\ Eva Šlesingerová, Eleonóra Hamar, Csaba Szaló
}

\begin{abstract}
The analysis of language, knowledge, and interpretations - and the practical consequences of this knowledge and these interpretations - forms the basic theoretical presupposition of all sociological inquiries into the phenomenon of "race." All forms of knowledge dealing with "race" are necessarily linked with practices of power constituting hierarchical orders of classification. Racist ideology by means of these orders constructs its objects and subjects, i.e., those who are racists and those who are stigmatised. Racist representations of the Other are closely interrelated with the discursive construction of the body as a space in which symbolic boundaries of impurity, hatred as well as health and desire are situated. The discursive regime of racism is not a by-product of modernity but one of its main cultural forms. The ideology of racism played a crucial role in legitimizing the emerging nation-state both in its internal efforts to normalize society and external attempts to colonize new lands.
\end{abstract}

KEYWORDS Race; Racism; Body; Ideology; Discourse

O rasismu se diskutuje už i v české společnosti poměrně dlouho: existuje několik významných iniciativ, které se snaží různým projevům rasismu čelit, téma rasismu je př́tomno v médiích a ve vědeckých publikacích, promítá se do kurikul vzdělávacích institucí a nejspíš bychom sotva našli člověka, který by nebyl schopen spojit s rasismem nějakou konkrétní událost či prŕihodu, jež se v české společnosti odehrála po roce 1989. Přesto všechno se zdá, že jen málokdy máme jasno $v$ tom, jak rozumět pojmu rasa, $v$ jakých případech a především v jakých významech ho adekvátně použít, jak nalézt rovnováhu mezi naším vnímáním existujících vnějších fyzických rozdílů mezi lidmi a mezi snahou zaujmout tolerantní teoretický a praktický postoj.

$\mathrm{K}$ lepší orientaci v těchto nejasnostech nám mohou pomoci zjištění a poznatky, které produkují sociální vědy. ${ }^{1}$ Ty nám v prvé řadě ř́kají, že pojem rasy je prostředkem myšlení, tj. určitou obecnou myšlenkou, jež prostřednictvím určité skupiny lidí zvýznamňuje realitu a lidskou zkušenost. Pojetí rasy jako prostředku myšlení umožňuje klasifikovat a třídit komplexní sociální realitu, jež se jednotlivcům často jeví jako nepřehledná. Z pojmu rasy jako instrumentu myšlení ovšem nelze vyvozovat existenci rasy jako sociální skupiny či populace. ${ }^{2}$ Jelikož jde o zásadní rozlišení, věnujme mu nyní v úvodní části textu podrobnější pozornost.

Sociální studia. Fakulta sociálních studií Masarykovy univerzity, 4/2007. S. 7-21. ISSN 1214-813X. Srov. Harrison (1995), Šmausová (1999), Mullings (2005).

Klasifikace a podoby třídění jsou vždy kulturně podmíněny. Klasifikace diferencí a odlišností, respektive podobností a stejností, je podmíněna schopností myslet určitým způsobem. Znamená to, 
Pojmy jsou vyústěním určitých zkušeností. Jinými slovy, utváření abstraktních pojmů se zakládá na konkrétní lidské zkušenosti. Pro naši úvahu o fungování jednoho ,jasně vymezeného“ prostředku myšlení to znamená, že obecný pojem rasy pramení ze zakoušení určitých forem fyzických jinakostí lidí, jako je např́iklad barva kůže a vlasů. Elementárním př́kladem takové zkušenosti je stanovování souvislosti mezi tělesnými a morálními rozdíly existujícími mezi jednotlivci. V každodenním rasismu se tento fakt vyjadřuje např́klad slovy ,všichni černí kradou“. Tento př́klad dobře vystihuje, že pojem rasy nevzniká čistě ze zkušenosti fyzické jinakosti lidí čili z běžného rozlišování objektivních tělesných rozdílů. ${ }^{3}$ Tělesná kategorizace je spojena s morální/hodnotící kategorizací již v zárodku takové zkušenosti: k barvě kůže se přiřazuje morální hodnota v podobě společensky odsuzované formy jednání (jíž může být v tomto př́ipadě odmítaná podoba obstarávání obživy).

Popisovaná situace se nám ale ukáže jako ještě složitější, dodáme-li, že abstraktní pojmy neodráží lidskou zkušenost př́mo. ${ }^{4}$ Vztah mezi pojmem a zkušeností není totiž vztahem prosté korespondence $\mathrm{v}$ tom smyslu, že bychom určité zkušenosti mohli přiřadit jeden odpovídající pojem. Mezi pojmem a zkušeností existuje vztah interpretační: pojmy se vytváŕí prostřednictvím výkladu konkrétních lidských zkušeností. Tak například zkušenost komunikace s duchovní bytostí skrze sluchové vnímání šepotu či zrakové vnímání zárících světel může generovat různá pojmová určení v závislosti na různých typech interpretačních rámců. Tuto zkušenost tak lze popsat jako setkání s andělem, jako halucinaci, jako sen nebo třeba jako auratické vidění spojené s migrénovými stavy. Tato pojmová určení jsou výsledkem interpretace zkušenosti a jako většina elementů pojmových aparátů mohou začít žít vlastním životem. A tak například pojem anděl, který měl původně vysvětlit určitý typ zrakové a poslechové zkušenosti, se od této zkušenosti osamostatňuje a naplňuje životní svět nejrůznějšími druhy andělů jako existujících bytostí.

K osamostatnění pojmu od lidské zkušenosti dochází také v případě pojmu rasa. Tento proces osamostatňování můžeme popsat jako zvěcnění (reifikaci), během něhož se ,zapomíná“ na skutečnost, že jde o pojem, který vznikl jako prostředek myšlení sloužící interpretaci konkrétních zkušeností. V tomto př́ípadě se bude předpokládat, že pojem rasa odkazuje k nějaké věci - přesněji sociální skupině -, jež existuje v sociální realitě sama o sobě jako typickým způsobem jednající aktér.

že kulturně dané klasifikace jsou závislé na konkrétních „režimech pravdy“, jejichž prostřednictvím jsou vytvářeny. Ke kritice tzv. ,grupismu“ srov. Brubaker (2004).

3 Určitá distinktivní vlastnost (jako např́klad bílá nebo černá barva kůže, štíhlost nebo tloušt'ka) se může stát viditelnou, ne-indiferentní a společensky průkaznou diferencí jedině tehdy, je-li vnímána a popisována někým, kdo je schopný tyto vlastnosti diferencovat. Existence takové vlastnosti jako vlastnosti distinktivní předpokládá tedy subjekt, který je zapojen do daného sociálního prostoru, a proto není indiferentní a vládne kategoriemi vnímání, klasifikačními schématy, které diferencování, rozlišování vytváří a umožňují. Navíc tato diference existuje pouze jako vztahová vlastnost, jako možné umístění v sociálním prostoru (Bourdieu 1998).

4 Pro odlišnost mezi pojmy blízkými zkušenosti a pojmy od zkušenosti oddálenými srov. Geertz (1983). 
Znamená to tedy, že myšlenkové struktury a pojmové aparáty žijící samostatným životem ovlivňují zpětně lidskou zkušenost. ${ }^{5}$ Naše zkušenosti jsou ovlivňovány pojmovým aparátem, jenž jako členové určité jazykové komunity máme $\mathrm{k}$ dispozici. A protože sdílíme určitý společný jazyk a pojmový aparát, sdílíme společně i základní nástroje pro uspořádání světa a osmyslňování zkušenosti. Přesahujeme tím „tady a ted“، našich každodenních životi̊, nebot' naše každodenní zkušenost je formována pojmovým aparátem vědění, který nekoření v naší vlastní zkušenosti, ale také ve zkušenosti jiných. Díky aktu přiřazení určitých pojmů a typifikačních schémat sociální realitě se pak vytvářejí sociální kategorie jinakosti či odlišnosti (Berger a Luckmann 1999). Pro nás je zde klíčové, že pro pochopení „,rasy“ máme začít zkoumáním jazyka, forem vědění a interpretací, a nikoliv studováním biologických znaků a tělesných charakteristik. Zkoumáme-li rasismus jako společenský fenomén, bude pro nás rozhodující jednak upozornění na praktické konsekvence, které z různých souborů vědění a interpretací vyplývají, jednak porozumění fungování a používání pojmu rasy v různých společenských kontextech.

\section{Rasa jako kategorie praxe a kategorie analýzy}

Prostřednictvím pojmu rasa lidé přiřazují sami sebe i druhé k určitým kolektivitám. Tyto kolektivity jsou uchopitelné pomocí různých kategorií sociálních identit, k jakým patř́ například národ, etnická skupina, náboženská komunita, sociální třída či v našem případě „rasa“. V tomto smyslu je ,rasa“ jedním z klasifikačních prostředků, jejichž prostřednictvím se sociální realita uspořádává a jejichž prostř̌ednictvím se určuje místo jednotlivce v sociální realitě. „Rasa“ tedy disponuje intenzivní skupino-tvornou silou.

Na základě pojmu rasy jsou většinou konstruovány dvě skupiny stojící vzájemně v opozici. Na jedné straně pojem rasy konstituuje rasistickou skupinu (tj. skupinu rasistů, které můžeme vymezit jako subjekty rasismu), na straně druhé konstituuje méněcennou, vůči prvnímu uskupení kontrastní skupinu (o které můžeme mluvit jako o objektu rasismu). Členové druhé jmenované skupiny přitom nemusejí předem sdílet skupinovou přináležitost, jež je jim v procesu rasistického nálepkování přisouzena. Častokrát až během následné reakce na stigmatizující praktiky volí jako jednu ze strategií konstrukce své identity právě potvrzení identifikace, jejímž prostřednictvím je definovali rasisté.

Z hlediska sociologie je však otázka ontologického statusu výše jmenovaných kolektivit sekundární. Relevantním problémem je zde proces institucionalizace vědění, praktik a mocenských vztahů, které jsou s těmito formami sociálních identit propojené. ${ }^{6}$ Jinými slovy, stěžejní otázkou sociologie není (a nemůže být), jestli něco takového jako „rasa“ existuje jako sociální skupina či nikoliv. Sociologicky relevantní jsou oproti tomu např́klad

5 Prostřednictvím reifikovaného pojmu rasa se tak vytvář́i i konceptuální možnost formulování rasistických vyjádření, která se ukotvují v tzv. „přirozeném“ řádu věcí, v nezpochybňované „,realitě“ (srov. Goldberg 1993).

6 Z perspektivy sociologie je problém ontologického statusu - bytí či existence - „rasy“ jako sociální skupiny součástí obecnějšího problému ontologického statusu již zmíněných kolektivit, vyjadřovaných kategoriemi národ, sociální třída, etnická skupina, náboženská komunita atd. 
(a) konsekvence vygenerované rasistickým typem vědění a jednání, jež „rasy“ považují za skupiny; (b) mocenské vztahy a principy rozdělení forem moci, které jsou výsledkem rasistického myšlení a jednání; (c) principy institucionalizace a legitimizace struktur diferencí vytvářených na základě rasismu.

Všechny výše zmíněné kategorie sociální identity (národ, etnická skupina, náboženská komunita, sociální třída, rasa) jsou jak kategoriemi praxe, tak kategoriemi analýzy. Jako kategorie praxe tvoří součást forem vědění, které jsou lidmi používané ve světě každodenních praktik. Jako kategorie analýzy pak odkazují k formám vědění, které používají vědci zkoumající tento svět a jednání lidí v něm (Bourdieu a Wacquant 1992).

Z hlediska sociologie je důležité si všímat, v jakých souborech vědění a v jakých situacích se objevují praktiky a výroky, v nichž se rasismus artikuluje. Abychom mohli tyto otázky přiblížit, můžeme nastínit analytický prostor, v němž hlavní třídicí osa rozlišuje mezi různými typy vědění, diskurzů a událostí. V souladu s ideou modernity budeme považovat tuto osu za analytickou hranici mezi oblastí vědy a oblastí každodenní praxe. Tato osa odděluje vědění zakládající se na analytických kategoriích od vědění, které v sobě zahrnuje kategorie každodenní praxe. Již toto naše rozlišení může poukázat na významové odlišnosti užití pojmu rasy v kontextu každodenních diskurzů politiky, publicistiky, hospodských diskusí, rodinných konverzací, či v kontextu vědeckých seminářů, konferencí, publikací, expertiz.

Komplexitu této problematiky lze přiblížit prostřednictvím dalšího zjemnění typologie různých forem vědění, diskurzů a situací, v nichž je pojem rasy použíán. Tyto různé oblasti se odlišují v rovině diskurzivních řádů, jež regulují, co lze a nelze vyslovit, kdo může určité výroky vyslovit, s jakým nárokem na platnost. V různých oblastech vědění, diskurzů a událostí platí jiná kritéria vymezující nároky na platnost vyslovených výroků. Hlavními oblastmi, které tvoří odlišné kontexty používání pojmu rasa, jsou: (a) Praktické vědění, diskurzy a události patřící do sféry každodennosti - sociální interakce, osobní rozhodování, rodinné aktivity atd.; (b) praktické vědění, diskurzy a události patřící do sféry veřejnosti - politika, vzdělávání, žurnalistika, veřejné podoby náboženství, umění atd.; (c) analytické vědění, diskurzy a události patřící do sféry prŕrodních věd - biologie, genetika, medicína atd.; (d) analytické vědění, diskurzy a události patřící do sféry sociálních věd - sociologie, historie, sociální antropologie, genderová studia, politologie atd.

Problematika používání pojmu rasy je tedy vždy otázkou jeho platnosti v jednotlivých sférách vědění, diskurzů a událostí. Diskurz artikulující ideu rasy může fungovat jako gramatika relevantního vědění a vidění, čili jako soubor pravidel vymezující správné užití a správnou formulaci výroků. Tyto diskurzy umožňují dále formulaci narativních strategií, jejichž výsledkem jsou srozumitelné a věrohodné příběhy sloužící k segregaci, eliminaci či normalizaci určitých typů subjektů ve společnosti. Jde o narativní strategie, které prostřednictvím př́iběhové formy vytvář́i koherenci, a tím i legitimitu rasistických výroků.

Problematika používání pojmu rasy se podobá problematice používání jiných pojmů a forem vědění, které vznáší nárok na platnost. Například pojem d'ábla není v současnosti považován za analytickou kategorii př́rodních a společenských věd, nicméně je součástí vědění každodennosti a přinejmenším v podobě metafory je také součástí jistých forem veřejného vědění. Klíčové je ovšem odlišit epistemologickou rovinu problematiky platnosti užívání pojmu rasy od sociologické problematiky předpokladů a konsekvencí používání tohoto 
pojmu v jednotlivých sférách vědění. Jinak řečeno, měli bychom odlišit (a) otázky týkající se toho, jestli je vhodné používat pojem rasy v rovině praktického vědění každodennosti, jestli má pojem rasy co pohledávat $\mathrm{v}$ politickém diskurzu, jestli je relevantní používat tento pojem jako analytickou kategorii $\mathrm{v}$ prrírodních a společenských vědách; a (b) otázky zkoumající předpoklady a konsekvence používání kategorie rasy např́íklad v politickém diskurzu přelomu 20. století, předpoklady a konsekvence používání pojmu rasy v praktickém vědění běžného Evropana, předpoklady a konsekvence užívání pojmu rasy v prrírodních a společenských vědách v první polovině dvacátého století.

Nejde samozřejmě o to, že by tyto dvě roviny otázek mohly či měly být úplně odloučeny. Jedním ze základních sociologických zjištění je totiž právě to, že platnost a vhodnost používání pojmů $\mathrm{v}$ různých sférách vědění, diskurzů a událostí velice úzce souvisí s jejich užitečností ve smyslu konsekvencí a předpokladů jejich použivání. Jinak řečeno, vhodnost používání a platnost pojmů se nemůže zredukovat na otázku jejich „pravdivosti““ ve smyslu jakési korespondence těchto pojmů s realitou.

$\mathrm{V}$ této rovině argumentace lze spatřovat zásadní odlišnost mezi prírodními a společenskými vědami, jelikož společenské vědy reflektují normativní konsekvence vlastních výroků a pojmů. Neznamená to však ani to, že by rovina epistemologická a sociologická měla být promíchána. Epistemologická kritika používání pojmu rasy nemůže nahradit sociologickou analýzu použivání tohoto pojmu. ${ }^{7}$ Kritika určité ideologie nespočivá v poukazu na to, že určitý pojem je nepravdivý a falešný, nýbrž v poukazu na symbolickou a mocenskou funkci, na předpoklady a konsekvence použivání tohoto pojmu.

\section{Ideologie rasismu}

Na základě předchozího textu lze tedy říci, že „rasa“ je slovo, že „rasa“ je pojem. „Rasa“ není sociální skupinou ani populací. Existují však sociální skupiny (hnutí či politické asociace), které se utvářejí kolem ideje, že jsou představiteli rasy ve smyslu kolektivity pobývající v prostoru „dějin“ a současně zakořeněné v prostoru „přírody“. Víceméně koherentní soubor takových představ můžeme považovat za rasistickou ideologii.

Rasismus jako ideologie má dva klíčové aspekty (srov. Balibar a Wallerstein 1991). Na jedné straně se rasismus vepisuje do určitých praktik a jednání - generuje určité typy jednání. Nenechat nastoupit někoho do autobusu, volit jistou politickou stranu, kupovat jistý typ novin, přiklánět se $\mathrm{k}$ určitým typům vysvětlování každodenní skutečnosti kolem nás, selektovat mezi známými podle určitého fyzického a morálního kódu, ovlivňovat své děti v tom, s kým se kamarádí, s kým se žení, vedle koho bydlí - vše uvedené představuje jenom malý

Epistemologie by však měla být v tomto kontextu chápána jako fenomén existující dějinně, jako distinktivní sociální praxe, jedna mezi mnohými (Rabinow 1984). Každá epistémé je přitom charakterizována určitým historicky specifickým režimem racionality a konkrétními procesy politiky pravdy. Diskurzivní pravidla vědění o rase podobně jako u jiných podob vědění vyvstávají z ekonomie epistemologické produkce, kde pravda je rozlišena od nepravdy. V tomto smyslu pravda o „rase“ odkazuje jak k soustavě procedur sloužících produkci, regulaci či distribuci výroků, tak $\mathrm{k}$ cirkulaci mezi různými institucemi moci, které vědění produkují a podporují. 
výčet př́kladů potenciálně rasistického jednání. Na straně druhé se rasismus jako ideologie krystalizuje v určitých typech diskurzů a forem vědění, jež jsou artikulovány především prostřednictvím stigmat jinakosti. Rasismus jako ideologie vytváří hranici mezi „my“ a „oni“, přičemž „oni“ jsou představováni a definováni jako méněcenní v morálním, estetickém a kognitivním smyslu slova. Rasisticky vymezení „oni“ jsou za všech okolností zlí, oškliví a hloupí. Stigmatický charakter těchto připsaných rysů spočívá v tom, že jinakost je viditelná a neměnitelná. Rasismus jako forma vědění připoutává člověka k jeho původu a ztotožňuje ho s jeho tělem, redukuje jeho lidství na otázku určitým zpo̊sobem zvýznamněných tělesných odlišností. ${ }^{8}$

Klíčovým rysem rasistické ideologie jako souboru vědění je přesvědčení o viditelnosti základních lidských charakteristik. Jinakost člověka (jako jedna z jeho základních charakteristik) může být reprezentována ${ }^{9}$ různými způsoby, přičemž rasistické představy staví symboliku těla a tělesnosti do popředí jako nejviditelnější, a proto nejnepochybnější podobu jinakosti. Pro rasistickou ideologii je tělo zásadní, protože je považované za jednoznačně „přirozený“ a viditelný objekt, který stojí v centru každodenní zkušenosti. Tělo se v rasistické ideologii nabízí jako metaforický prostředek rozlišení čistého od nečistého, přijatelného od nepřijatelného (Goldberg 1993). Právě symbolika těla totiž většinou slouží zájmům rasistického dokazování již zmíněných charakteristik zlý, ošklivý a hloupý připisovaných objektům rasismu.

Zkoumáme-li rasistickou ideologii jako určitý soubor vědění, bude relevantní také otázka, jakými způsoby fungují praktiky různých reprezentací/zobrazení „Druhých“. Roli těchto praktik můžeme sledovat ve třech dimenzích. Za prvé, praktiky produkující vědění se realizují vždy v určitém institucionálním prostředí, ve kterém je produkce vědění sociálně organizována a regulována. Produkce rasistického vědění o „Druhých“ je propojena např́íklad s ustanovením knihoven, výzkumných ústavů a archivů, se psaním a vydáváním učebnic. V těchto institucionálních prostředích vzniká autorizovaný „seznam“ jak typů lidí, kteří se zařazují do kategorie „Druhých“, tak prostorů jejich pobývání (kolonie, slumy, plantáže, rezervace). Tyto prostory přitom nejsou pouze místy, kde se tito „Druzi““ nacházejí, nýbrž jsou také prostory, v nichž mohou být pozorováni a zkoumáni - slouží tudíž jako laboratoře, v nichž je epistemologický konstrukt rasy testován.

Za druhé, rasové rozdíly mezi subjekty vznikají v rámci rasistického diskurzu, v němž se prolínají nejrůznější jazyková vyjádření odkazující k pojmu rasa (Goldberg 1990). Diskurz rasy se neskládá pouze z popisných výroků, nýbrž je konstituován skrze nejrůznější normy, nadávky, př́iběhy, prŕivlastky, vtipy, víry, pomluvy. Vědění o „rase“ se v tomto diskurzu vytváří prostřednictvím rasové diferenciace, jež se realizuje ve dvou diskurzivních prakti-

8 Zde je zajímavé všimnout si toho, že tělesné znaky, které jsou v rasistické ideologii považovány za přirozené, existují vždy v rámci určitého souboru vědění o rase. „Stačí si... připomenout pár historických příkladů, aby bylo zřejmé, že nejen sociální a politický význam fyzických rozdílů, ale i výraznost těchto rozdílů samotných je kulturním konstruktem" (Barša 1999: 101-102).

9 Nemáme zde na mysli reprezentaci mimetickou, zrcadlící realitu, ani intencionální, analyzující záměr autora. Zajímá nás sociálně konstruovaný způsob reprezentace ve smyslu zobrazení, kde význam určitých vyjádření, obrazů, ikon je sociálně vytvářen prostřednictvím interpretací (srov. Hall 1997). 
kách: v pojmenovávání a v ohodnocování. Pojmenovávání a ohodnocování přitom ve výše vyjmenovaných jazykových vyjádřeních mohou fungovat zároveň. Rasistické vtipy jsou dobrým př́kladem situací, kdy je samotné pojmenování postavy („Cikán“, „Dežo“, „Žid“, „Kohn“, „Křovák“, „Rákosník“, „Šikmooký“) již jejím implicitním ohodnocením. Vědění o rasově označeném „Druhém“ je tedy konstituováno na základě prolínání různých jazykových vyjádření, v nichž se rasová přirozenost „Druhého“ objevuje v podobě různých informací o jeho charakteru, kultuře, historii a tradicích.

Za třetí, praktiky rasistického diskurzu konstruují taková vypodobení skutečnosti, která jsou předkládána jako věrohodná, autentická a pravdivá. Autenticita výpovědí rasistického diskurzu je založena na tom, že přijímá tělo jako hlavní nástroj reprezentace/zobrazení stigmatizované jinakosti. Jinak řečeno, subjekty rasismu prrijímají určité ikony a obrazy těl jako autentická a věrohodná vypodobení skutečnosti. Z perspektivy sociologie je přitom jasné, že ikonické zobrazení těl rasové rozdíly mezi lidmi neobjevuje, ale tvoří, a to pomocí zobrazení tělesných rozdílů jako přirozeného stavu věcí.

„Druhý“ je pro subjekty rasismu vždy jakýmsi alter egem, tedy někým, kdo určuje hranice sebeidentity rasistů. „Druhý“ je tím, kým rasista není. Je cizincem, který je vždy blízko i daleko, je známým a tajemným zároveň. Tato skutečnost dobře ukazuje, že rasistická ideologie do sebe nezahrnuje pouze objekty rasismu (,druhéc), ale stejně tak i subjekty rasismu (o skupině rasisticky smýšlejících). Společenské kořeny rasismu (podobně jako každé jiné ideologie) můžeme tedy odhalit prostřednictvím teorie ideologie jako prostředku prosazování zájmů, respektive prostřednictvím teorie ideologie jako nástroje kompenzace napětí (srov. Geertz 1993). Obě tyto teorie věnují totiž pozornost subjektům rasismu, o jejichž zájmy a kompenzace jde.

Vycházíme-li z teorie, jež ideologii pojímá jako prostředek prosazování zájmů, můžeme rasismus považovat za prostředek boje o moc. Pojetí rasismu jako ideologické zbraně vysvětluje působení idejí zakotveností těchto idejí v materiálních zájmech jejich nositelů. Potřebnou motivaci $\mathrm{k}$ tomu, aby tito lidé věřili, mysleli a jednali na základě rasistické ideologie, formují jejich vlastní zájmy. A protože zájmy lidí jsou dány tím, jakou pozici tito lidé na „hracím poli“ společenského boje o zdroje zastávají, prrítomnost ideologie rasismu v určitých vrstvách společnosti bude spíše symptomem latentního sociálního konfliktu než zlomyslnosti či nevzdělanosti př́slušných lidí.

Proč však právě rasismus působí jako efektivní ideologická zbraň v určitých segmentech společnosti? Lze jeho „úspěšnost“ vysvětlit „úrovní“ vzdělanosti či morálního uvědomění „rasistư“? Hraje zde roli to, že tito lidé nejsou schopni své zájmy vyjádřit kultivovanějšími ideologickými prostředky? Nebo je dokonce rasismus falešnou ideologií, jež ve skutečnosti slouží zájmu jiných sociálních skupin než těch, které $\mathrm{v}$ ideu rasy věří? $\mathrm{Z}$ této teoretické perspektivy se situace stává ještě komplexnější, je-li ona ideologická zbraň užívána nehledě na pozici či místo jejích nositelů v sociálním prostoru, čili působí-li ve všech segmentech společnosti. Jinak řečeno, v př́padě, kdy (a) nelze lokalizovat autentické nositele této ideologie nebo (b) se tato ideologie ukazuje být součástí samotného jádra institucionální struktury a sociálního řádu společnosti, tj. státu.

Sociologie se snaží tento složitý fenomén vysvětlit další teorií, tj. již zmíněnou teorií ideologie jako nástroje kompenzace napětí. Toto pojetí ideologie vysvětluje komplexitu 
situace tím, že předpokládá př́tomnost určité univerzálně dané (tj. ve všech koutech sociálního pole prrítomné) charakteristiky lidí i samotného sociálního pole, tedy př́tomnost napětí. Ideologie rasismu toto napětí, jež vzniká jednak z důvodu nedokonalé integrace různých aspektů individuální existence lidí, jednak z důvodu nedostatečné integrace společnosti jako celku, kompenzuje. Nesoulad mezi touhami, sociálními normami a realitou vede ke vzniku psychických tenzí, které pak slouží jako základ motivace pro přijetí ideologické formy vysvětlení individuálních nezdarů jedinců i společenských problémů.

$\mathrm{V}$ př́padě teorie ideologie jako nástroje kompenzace napětí - podobně jako $\mathrm{v}$ př́padě teorie ideologie jako zbraně - můžeme rasismus pojmout jako znak či symptom, jenž na něco odkazuje. Zatímco z perspektivy ideologie jako zbraně může být rasismus považován za symptom sociálního konfliktu, z perspektivy teorie ideologie jako nástroje kompenzace napětí bude př́tomnost rasismu vysvětlována jako symptom nedokonalé sociální integra$c e$. Je zde přitom důležité upozornit na jeden klíčový rozdíl. Není totiž jedno, jestli budeme problém sociální integrace chápat $\mathrm{v}$ sociálně politickém smyslu slova jako nedostatečnou sociální integraci subjektů rasismu do společnosti, nebo jestli se na problém sociální integrace budeme dívat $\mathrm{z}$ perspektivy sociologie, jež poukazuje na strukturální předpoklady této situace. Samotná institucionální struktura společnosti, jež jedincům nabízí sociální role, identity a možné životní dráhy, může být v určitých obdobích nekonzistentní. Znamená to, že může docházet $\mathrm{k}$ tomu, že společnost bude klást nesouměřitelné nároky na jednotlivce (srov. Habermas 2000).

Odhalením sociálních kořenů ideologie rasismu však nelze dostatečně dobře vysvětlit proces symbolického formování ideologie, tedy toho, jak vzniká propojenost určitých idejí na jedné a zájmů nebo emocí na druhé straně (Geertz 1993). Pro porozumění fenoménu rasismu je proto nezbytné zabývat se také cestou, jež vede od emocí či zájmů ke společně sdílenému významu určitých znaků, jako jsou např́klad barva kůže, typ krve či genů. Symbolická moc znaků totiž nepramení z jejich původu, tj. z kulturních či sociálních kořenů těchto symbolů. Vysvětlující a identitu tvořící síla symbolů působí autonomně a může oslovit aktéry z různých částí sociálního pole. Právě z tohoto důvodu je zásadní, abychom si kromě konceptu rasy všímali i dalších klíčových pojmů diskurzu rasismu. Ideologie rasismu a idea rasy mohou získat symbolickou moc jedině v konstelaci s dalšími pojmy, jako jsou např́íklad boj, př́roda, dějiny a zdraví. Symbolická moc ideologie rasismu totiž spočívá v jeho teoretické/vysvětlující funkci. Tuto vysvětlující funkci uskutečňuje rasismus, podobně jako každá ideologie, prostřednictvím nastínění „mapy“ světa, jež nabízí jedincům orientaci ve společnosti díky jasně vyznačeným hranicím a stezkám. Z hlediska vysvětlující funkce rasismu je klíčové, že ideologie rasismu si nárokuje status vědy, přičemž tento svůj nárok na vědeckost v mnoha př́ípadech úspěšně prosazuje. Jde o nárok, podle nějž je ona „mapa“ rasismu založená na př́rodovědecké taxonomii, z čehož by mělo vyplývat, že vědecká pravdivost rasismu zaručuje správnost vlastní „mapy“ sloužící orientaci ve společnosti.

Nicméně právě tento nárok na prírodovědecké zakotvení je prvkem, který odhaluje nevěrohodnost sociální mapy rasismu. Tato nevěrohodnost je však viditelná pouze pro ty, kteří jsou s to připustit, že odlišnosti mezi člověkem a zvířaty, mezi kulturou a prírodou, jsou tak zásadní, že mapa založená na př́rodovědném vědění nemůže sloužit pro orientaci v sociální realitě. 


\section{Genealogie diskurzivního řádu rasismu}

Při sledování genealogie diskurzivního řádu rasismu bychom měli vycházet z úzce propojeného vztahu mezi mocí a věděním. Jak na to poukázal Michel Foucault (2000a), tento vztah ovšem nelze redukovat na vztah politické moci a ideologie. Ideologie, jako určité soubory vědění, nepochybně sehrávají důležitou roli ve sfére politiky. Neméně důležitou roli však sehrávají také ve sféře vzdělávání, umění a každodenní reality. Navíc ne všechny soubory vědění propojené s mocí jsou nutně ideologiemi (jsou to např́klad soubory vědění právní, statistické, demografické, medicínské, psychiatrické, technologické, administrativní atd.). Mechanismy moci - které bychom neměli pojímat pouze ve smyslu politických praktik - nemohou fungovat bez aparátů vědění.

Mechanismy moci prosakují celou společností a jako takové předpokládají, že pole jejich aplikace je totožné s polem vědění. Znamená to, že pole působení moci je zároveň polem produkce vědění - analytickým prostorem pozorování, klasifikace a vysvětlování (Foucault 2000b). Strategická racionalita moci je závislá na poznávání, na produkci vědění, a proto není vztah moci a vědění ztotožnitelný se vztahem zpětného ospravedlňování politické autority mýtem. ${ }^{10}$

Význam připisovaný „rase“ se postupem času výrazně měnil. Pojem rasy se v Evropě objevuje v sedmnáctém století v jiném významu, než jak ho pojímají rasistické ideologie dvacátého století. Podle Foucaulta (2003) vzniká pojem rasy jako součást historicko-politického diskurzu o společnosti. Ústředním pojmem tohoto diskurzu je přitom pojem války. Historicko-politický diskurz se utváŕí v konfrontaci s diskurzem, jenž společnost pojímá prostřednictvím filosoficko-právních konceptů a argumentů.

V historicko-politickém diskurzu slouží pojem války jako hlavní metafora, jež vysvětluje povahu sociálních vztahů. Válka a sociální vztahy vznikající v rámci boje jsou v tomto diskurzu považovány za esenciální základ moci a společnosti. Základní struktury, pojmy a argumenty tohoto diskurzu jsou př́tomné i v současných formách vědění, které pojem rasy používají. Důležité je ale připomenout, že tyto pojmy a argumenty necharakterizují pouze rasistické diskurzy a mohou být funkční dokonce i bez propojenosti s pojmem rasy.

Foucault (2003) ukázal, jak se historicko-politický diskurz v podobě systematického vědění artikuluje poprvé v sedmnáctém století, tj. v době formování absolutistických států v Anglii a ve Francii. Až na sklonku devatenáctého století vykrystalizovala rasistická, biologicko-eugenická podoba tohoto historicko-politického diskurzu o společnosti. Tento diskurz se ve svých počátcích artikuloval jako forma resistence a kritiky absolutistických snah monarchií. Jeho kritika byla založena na alternativním vyprávění historie (counter history) počátků společností. Toto alternativní vyprávění historicko-politického diskurzu spočívalo ve zpochybnění legitimity sociálního řádu: podkopávalo „přirozenost“ instituce práva a politické autority, kterou si nárokoval již zmíněný filosoficko-právní diskurz.

10 Moderní koncept ideologie je charakterizován třemi vzájemně propojenými tvrzením: (a) ideologie je definována jako opak ,pravdy“, ideologie je falešnou reprezentací; (b) ideologie je produkována subjektem (individuálním, kolektivním) za účelem skrýt pravdu; (c) ideologie je sekundární vzhledem k něčemu více reálnému, na čemž ideologie parazituje (srov. Rabinow 1984). Domníváme se, že je nutno odmítnout všechny tyto nároky. 
Historicko-politický diskurz pojímá právo a autoritu jako produkt boje. Právo a autorita jsou zde vykládány jako sociální instituce, které vznikají v důsledku války. Přestože tento argument odhaluje „krvavý původ“ práva a autority, nepředstavuje ještě radikální kritiku filosoficko-právního diskurzu, jenž o válce podává jiný obraz. Ve filosoficko-právním diskurzu je idea války vylíčena negativně - v podobě vážné hrozby, jež přichází jako alternativa dosavadního stavu práva a autority. Válka je jinými slovy označením pro neblahý stav, který ukončil vládu práva a autority. Radikálně-kritický argument historicko-politického diskurzu spočívá naopak v esencializaci války, tj. ve výrazném zpochybnění představy, že právo a autorita jsou s to nastolit poválečný stav konsensu a míru. Podle tohoto diskurzu je společnost ve stavu válčení neustále. Po uzavření mírových dohod či po vítězství jedné strany válka pokračuje v pozadí, tj. za kulisami práva a autority. A z toho plyne, že boj je přítomný v každém segmentu společnosti a ve všech mocenských praktikách i v době míru. Permanentní boj se stává v tomto diskurzu (tj. ještě dávno před darwinismem!) skutečným hybatelem světa, společností a lidského jednání.

Ve filosoficko-právním diskurzu je společnost reprezentována hierarchicky: společnost sestává z různých stavů, hodností a úr̆adů (Foucault 2003). Tato hierarchická reprezentace se v podmínkách historicko-politického diskurzu hroutí do reprezentace binární. Ta je konstituována dvěma bojujícími kolektivitami, neboli dvěma typy lidí. V tomto klasifikačním řádu nemůže existovat neutrální subjekt: každý jednotlivý člověk musí být zařaditelný, musí patřit do jedné či druhé kategorie binární opozice. Musí být „stejný jako my“ nebo ,jiný jako oni“. Rasa se v tomto diskurzu začíná objevovat jako slovo, jež označuje bojující strany (races). Přes svůj kritický potenciál tento diskurz tedy, jak vidíme, nepřekonává ideologickou formu vědění, svou symbolickou moc totiž staví také na mytologických prvcích. Jeho kritický potenciál spočívá v tom, že nabízí alternativní mytologii. Mytologie dávných bojů, hrdinů, nespravedlivých porážek a heroických vítězství konstituuje jak utopickou naději v lepší budoucnost, tak imaginární podobu bojujících kolektivit. A kdo to vlastně bojuje? Představa bojujících hrdinů, králů a rytírů se postupně rozšiřuje a ve výsledku bude zahrnovat také „lid“. Lid se konstituuje jako subjekt, který mají bojující hrdinové „bránit a zastupovat“. Jakmile se válka stává permanentním a skrytým bojem, jakmile se už nebojuje výhradně na bojištích a v době bitev, bojovníkem se stává každý.

Jednu z klíčových funkcí tohoto diskurzivního řádu tedy představuje klasifikace bojujících kolektivit. Kdo jsou však ony dvě ,,rasy“, které spolu v proudu dějin permanentně válčí? Jaká je povaha těchto bojujících kolektivit? Jak můžeme věrohodně reprezentovat binární schéma společnosti? To jsou latentní otázky, na které formuluje historicko-politický diskurz své odpovědi v podobě př́iběhů o původu boje, v podobě příběhů o invazi a kolonizaci. V počátcích formování historicko-politického diskurzu permanentního sociálního boje, tedy ještě před jeho biologizací, byly bojující kolektivity/rasy představovány v podobě podmaněných domorodců na jedné straně a v podobě cizích okupantů na straně druhé. Představy o těchto kolektivitách se artikulovaly např́klad v př́ibězích o invazi Normanů do domoviny Anglosasů nebo o invazi Franků do domoviny Galů. ${ }^{11}$

11 Pro kritickou analýzu Foucaultova textu Society Must Be Defended srov. Marks (2000). 
Biologizace těchto kolektivit má své počátky $\mathrm{v}$ symbolické reprezentaci, jež je pojímá v podobě „lidu“ (dnes bychom řekli „etnické skupiny“), tedy již nikoliv jako kolektivitu bojovníků sdružených za účelem válčení (Armstrong 1982). Jinými slovy, počátkem biologizace bojujících kolektivit (označovaných v politicko-historickém diskurzu jako rasy) je jejich „etnizace“. K tomuto aktu etnizace dochází jak pod vlivem diskurzu materialistické anatomofyziologie, tak pod vlivem diskurzu filologie. Vliv těchto forem vědění, které si nárokují status vědy, se posiloval díky sociálním procesům, které byly propojeny s rodícím se nacionalismem a kolonialismem (Stoler 1995).

Etnizace ras jako bojujících kolektivit je však pouze jednou z diskurzivních strategií reprezentace. Další realizovanou strategií byla podle Foucaulta (2003) reprezentace, jež permanentní válku ve společnosti nepojímala $\mathrm{v}$ podobě boje mezi domorodci a cizinci, nýbrž v podobě „občanské“ války. Jinak řečeno, jde o konceptualizaci, jež si válčící strany představuje (dávno před Marxem!) v podobě „sociálních trríd“. Tato podoba historicko-politického diskurzu spatřuje hranici, jež odděluje bojující strany, v rozdílech mezi bohatými a chudými, neboli mezi držiteli moci a bezmocnými.

Nakonec je třeba zmínit se o nejznámější formě reprezentace bojujících kolektivit: o biologicko-sociální strategii. Tato strategie diskurzivní reprezentace krystalizuje pod vlivem evolucionismu a ideje kolektivního boje za přežití. Z hlediska diskurzivního řádu historickopolitického diskurzu je zásadní, že do sebe inkorporuje jak etnizující, tak sociálně-třídní linii. Kromě toho, že rasy v tomto diskurzu získávají charakteristiku biologicky vymezených skupin - tj. etnických či hyper-etnických skupin zakotvených v prírodě -, reinterpretuje se prostřednictvím sociálně-třídní linie konstituovaný význam vnitřní divize společnosti na dominantní a podřízené skupiny do podoby vnitřní segmentace rasy na zdravou a nezdravou část. Jak rasové skupiny, tak jejich zdravé a nezdravé části jsou přitom charakterizovány jako existující v permanentním konfliktu.

Tato biologicko-medicínská vize dvojího boje - mezi rasami o prežití na jedné straně a uvnitř rasy proti degeneraci na straně druhé - se stává ideologií normalizačních snah moderní společnosti. Vize tohoto dvojího boje výrazně krystalizuje v devatenáctém a dvacátém století. Vnitřní a vnější boj se vzájemně předpokládají a posilují. Vize boje proti vnějšímu nebezpečí ospravedlňuje kolonizaci a zároveň zdůvodňuje represi vnitřních „nezdravých elementư", které ohrožují národ zevnitř a vedou $\mathrm{k}$ jeho degeneraci. $\mathrm{V}$ př́padě kolonizace jde o boj proti „kontaminaci rasy nezdravými elementy“, kterou by mohla způsobit sexuální a morální koexistence s kolonizovanými „domorodci“. V př́padě vnitřní normalizace společnosti rozdělené na zdravé a nezdravé subjekty jde o boj za společnost, která je ohrožena řadou heterogenních prvků, jež jsou pojímány jako nepřátelé, kteří se vplížili do původně „Zdravéc“ společnosti.

Při uspořádání moderní společnosti tedy hraje významnou roli komplex moci a vědění, v němž idea „rasy“ zaujímá ústřrední pozici. Vnější a vnitřní boj mezi nepráteli dal vzniknout hranici mezi těmi, kteř́ by měli být ponecháni naživu, a těmi, kteří by měli zemřít (Stingelin 2003). K této společenské transformaci docházelo v době rozvoje národních celků, tedy $\mathrm{v}$ době, kdy národní státy začínaly kontrolovat obyvatelstvo $\mathrm{v}$ rámci určitého teritoria. Strategie národního sjednocení se utvářela prostřednictvím tzv. biomoci (Foucault 1999). Moderní strategie biomoci směřuje k produkci „lidu“/,populace“ jakožto politického celku 
zdravých, plodných, rozmnožujících se lidí. Biomoc působí jak skrze dohled nad národními populacemi, tak skrze kontrolu individuálních těl občanů. Biomoc je jednoduše řečeno vtažením života a jeho mechanismů do sféry vzájemného působení moci a vědění.

Do sféry moci a vědění je život vtažený skrze regulace a vytváření těl. $V$ průběhu dějin se komplex moci a vědění rozvíjel ve dvou vzájemně propojených, analyticky rozlišených oblastech. První z těchto oblastí se soustředila na tělo jako na stroj: na zvyšování a zdokonalování jeho schopností, na růst jeho užitečnosti a poslušnosti, na jeho zakomponování do sfér administrativní správy a ekonomické kontroly. Tuto oblast - zahrnující v sobě disciplinační praktiky moci - nazývá Foucault (2000b) anatomo-politikou lidského těla. Do druhé oblasti patří moc nad životem, jež se soustředila na „tělo“ populace: na plodnost, porodnost, úmrtnost, zdravotní stav apod. Tyto procesy jsou ovlivňovány nepřeberným množstvím intervencí a rozličnými způsoby regulativních kontrol. O těchto praktikách mluví Foucault (1999) jako o biopolitice populace. Tím, že jsou jevy vlastní lidskému životu vtaženy do rádu moci a vědění, se ukazuje, že těla nejsou čistě prírodní či biologickou entitou, ale spíše diskurzivními objekty, jejichž prostřednictvím jednotlivci internalizují moc a vědění (neboli, v duchu nastíněné metafory, moc a vědění se do nich „vtěluji“; Foucault 2000a).

Podle Loïc Wacquanta (1997) je klíčovou otázkou vyplývající z foucaultovské analýzy rasismu to, $\mathrm{v}$ jaké podobě působí rasistické praktiky dominance $\mathrm{v}$ rámci biomoci moderních společností. ${ }^{12}$ Rasismus je propojen způsoby selekce a distribuce nerovnosti: „rasa“ získává význam jako kategorie sociální klasifikace, která úspěšně propojuje moderní disciplinační aparát moci a vědění s představou obrany společnosti před různými „rizikovými faktory“. Rasismus tak slibuje odlišit sociální skupiny vhodné k sociální inkluzi od skupin biologicky odsouzených k sociální exkluzi. Tím, že určuje kritérium inkluze na základě potenciálu převzít národní dědictví, rasismus přispívá $\mathrm{k}$ růstu symbolické moci nacionalismu.

Rasismus má v současné pozdně-moderní sociální realitě symbolickou sílu do té míry, do jaké umožňuje pojmout a ospravedlnit praktiky, které zabezpečují odlišení a eliminaci „nezdravé“ části společnosti. Rasismus nabízí jakési řešení dilematu spočívajícího v tom, jak může strategie moci usmrcovat a vylučovat přesto, že si vysoce cení života a snaží se o jeho prodloužení, rozmnožení a glorifikaci (Foucault 1999). Symbolická síla současného rasismu spočívá v nabídnutí „mapy“, jež poskytuje orientaci v současné sociální realitě tím, že sociálno pojímá jako biologické kontinuum (například populaci, obyvatelstvo, lid či lidský druh). Tato „mapa“ zároveň uspořádává populaci do hierarchického řádu, jenž směřuje od biologicky „podřadných“ a „nekvalitních“ k „zdravým“ a „dokonalým“.

Současné podoby rasismu jsou tedy centrálním elementem řádu moci a vědění, jenž produkuje společenskou normalitu. Neustále probíhající institucionalizovaná produkce „normálních těl vyžaduje vytváření specifického vědění o tělech: souborů norem, kvalifikace odchylek, ohodnocení jinakostí a strukturace intervencí. V této perspektivě rasismus vytvárí homogenizaci a hierarchizaci - nikoliv protiklady, ale komplementarity“ (Lemke 2003: 161).

Loïc Wacquant (1997) ve svém kritickém komentáŕi k práci Ann Laury Stoler klade důraz na to, že genealogické a diskursivní analýzy rasismu je třeba doplnit analýzou sociálních mechanismů a praktik rasistických forem nadvlády. 


\section{Závěr}

Zásadním východiskem sociologické analýzy rasismu je to, že př̀ snaze o pochopení „rasy“ začíná zkoumáním jazyka, forem vědění, interpretací a praktických konsekvencí, které z těchto vědění a interpretací vyplývají, tedy nikoliv analyzováním biologických znakủ či tělesných charakteristik př́slušníků tzv. populací. Jinak řečeno, zkoumáme-li rasismus jako společenský fenomén, bude pro nás rozhodující porozumění fungování a používání pojmu rasy v různých společenských kontextech. Každé vědění o „rase“ je propojeno s praktikami moci, které konstituují kulturně podmíněné hierarchické řády a klasifikace, jež přispívají $\mathrm{k}$ reprodukci rasistického vědění.

Rasistická ideologie vytváří své subjekty a objekty, tj. skupinu rasistů a skupinu stigmatizovaných. Ideologii rasismu je možné chápat jako diskurzivní formu vědění a moci, v jejímž rámci se vytvář́ symbolická reprezentace objektů i subjektů rasismu. Objekty rasismu mohou sledovat strategii odporu vůči stigmatizujícímu nálepkování. Jejich reakce na rasismus však často spočívá v potvrzení stigmatizující identifikace. V souvislosti s reprezentací rasově definovaných „Druhých“ a jejich sociálních identit jsme v našem textu představili tělo jako diskurzivní objekt, do kterého jsou prostřednictvím ideje rasy umístovány symbolické hranice nečistoty, nenávisti, ale i zdraví či touhy. V tomto smyslu se diskurzivní rád „rasy“ neukazuje jako vedlejší produkt, nýbrž jako jeden z významných formujících diskurzivních řádů modernity. Při konstituci národního státu, jeho zdravé, plodící, rozmnožující se populace umožnila ideologie rasismu pojmout a ospravedlnit jak koloniální boje navenek, tak normalizačního boje uvnitř národa.

Závěrem je důležité si připomenout, že ne všechna vyjádření, jednání či instituce, jež můžeme označit za rasistické, musí nutně odkazovat k barvě kůže, lebečnímu indexu či tvaru očí. Rasistické obsahy může nést nejen biologizace, ale také jiné formy esencializace charakteristik určitých sociálních skupin. Konkrétně se může jednat o „kritiku“ nošení určitého typu oblečení, používání jistého jazyka, přináležení k nějaké konkrétní kulturní tradici.

Staré významy konceptu „rasy“ však s nástupem kulturního rasismu nevymizely. Konsekvencí veřejného používání rasistických pojmů spojených s genetikou může být to, že se revitalizuje staronový kulturní kód sloužící hierarchizaci nových a dokonalých těl. Současný rozvoj nových biotechnologií, výzkumů DNA, výzkumů kmenových buněk, nových reprodukčních technik, terapeutického klonování apod. oživuje diskurz „biopolitiky“ a ideu rasy v nových společenských souvislostech. ${ }^{13}$

Zakotvení vlastností člověka či kulturního dědictví bud' v biologické podstatě genetického kódu, anebo v esencialisticky pojímaných kulturních charakteristikách poukazuje na flexibilitu rasistické ideologie. Jak jsme se snažili ukázat také sledováním genealogie rasismu,

13 Vývoj biotechnologií rozšiřuje pole nejen dosud známých možností jednání, nýbrž umožňuje i nový typ státních či expertních zásahů a regulace - tedy i nové formy biopolitiky. To, co bylo dosud „dáno“ jako organická přrirozenost, co mohlo být nanejvýš pouze „šlechtěno“, se nyní posouvá do oblasti cílených zákroků. Stírá se hranice mezi přirozeností, kterou ,jsme“, a organickým vybavením, které si sami „dáváme“ (srov. Habermas 2003). 
rasismus nečerpá svou symbolickou sílu z podstaty či esence, jež by byla jednou a provždy fixovaná. Jeho symbolická moc spočívá oproti tomu v přizpůsobivosti, jež umožňuje strategickou inkluzi nových elementů vědění a flexibilní reagování na proměny sociální reality.

\section{Literatura}

Armstrong, J. A. 1982. Nations before Nationalism. Chapel Hill: University of North Carolina Press.

Balibar, E.; Wallerstein, I. 1991. Race, Nation, Class. Ambigious Identities. London: Verso. Barša, P. 1999. Politická teorie multikulturalismu. Brno: CDK. 1999.

Berger, P. L; Luckmann, T. 1999. Sociální konstrukce reality. Pojednání o sociologii vědění. Brno: CDK.

Bourdieu, P.; Wacquant, L. J. D. 1992. An Invitation to Reflexive Sociology. Chicago: Chicago University Press.

Bourdieu, P. 1998. Teorie jednání. Praha: Karolinum.

Brubaker, R. 2004. Ethnicity without Groups. Cambridge, Mass.: Harvard University Press.

Foucault, M. 1999. Dějiny sexuality. Vưle k vědění. Praha: Hermann.

Foucault, M. 2000a. Power. London: Penguin.

Foucault, M. 2000b. Dohližet a trestat. Praha: Dauphin.

Foucault, M. 2003. Society Must Be Defended. Lectures at the College de France, 1975-76. New York: Picador.

Geertz, C. 1983. ,'From the Native point of View': On the Nature of Anthropological Understanding." In Local Knowledge, Further Essays in Interpretive Anthropology. New York: Basic Books, s. 55-70.

Geertz, C. 1993. „Ideology as a Cultural System“. In The Interpretations of Culture. London: Fontana, s. 193-233.

Goldberg, D. T. 1990. „The Social Formation of Racist Discourse“. In Goldberg, D. T. (ed.) Anatomy of Racism. Minneapolis: Minnesota University Press.

Goldberg, D. T. 1993. Racist Culture. Philosophy and the Politics of Meaning. Oxford: Blackwell.

Habermas, J. 2000. Problémy legitimity v pozdním kapitalismu. Praha: Filosofia.

Habermas, J. 2003. Budoucnost lidské přirozenosti. Na cestě k liberální eugenice? Praha: Filosofia.

Hall, S. 1997. „The Work of Representation.“ In Stuart Hall (ed.) Representation: Cultural Representation and Signifying Practices. London: Sage, s. 13-74.

Harrison, F. V. 1995. „The Persistent Power of ,Race“ in the Cultural and Political Economy of Racism." Annual Review of Antropology, 24: 47-74.

Lemke, T. 2003. „Rechtssubjekt oder Biomasse? Reflexionen zum Verhältnis von Rassismus und Exklusion“. In: Martin Stingelin (ed.) Biopolitik und Rassismus. Frankfurt am Main: Suhrkamp Verlag, s.160-183.

Marks, John. 2000. „Foucault, Franks, Gauls.“ Theory, Culture and Society, 17(5): 27-147.

Mullings, L. 2005. „Interrogating Racism: Toward an Antiracist Anthropology.“ Annual Review of Antropology, 34: 667-693. 
Rabinow, P. 1984. „Representations Are Social Facts: Modernity and Post-Modernity in Anthropology“. In: James Clifford, George E. Marcus (eds.). Writing Culture. The Poetics and Politics of Ethnography. Berkeley: University of California Press, s. 234-261.

Stingelin, M. (ed.) 2003. Biopolitik und Rassismus. Frankfurt am Main: Suhrkamp Verlag.

Stoler, A. L. 1995. Race and the Education of Desire: Foucault's History of Sexuality and the Colonial Order of Things. Durham: Duke University Press.

Wacquant, L. J. D. 1997. „For an Analytic of Racial Domination.“ Political Power and Social Theory, 11: 221-234.

\section{Autorky a autor}

Eva Šlesingerová působí na Katedře sociologie, oboru Sociální antropologie Fakulty sociálních studií Masarykovy univerzity v Brně, kde vyučuje předměty Současná sociální a kulturní teorie, Sociální antropologie a historie tělesnosti, Rasismus a idea „rasy“ a další. Zabývá se tématy konstrukce sociálních a kulturních identit, tělesnosti a jejich reprezentacemi v populární kultuře.

Kontakt: eslesi@fss.muni.cz

Eleonóra Hamar působí na Ústavu religionistiky Filozofické fakulty Masarykovy univerzity v Brně. Její výzkumné aktivity se zaměřují na narativní konstruování identit. Zajímá se o sociologii nacionalismu, o kulturní dějiny moderního židovství a v poslední době rovněž o teoretickou religionistiku.

Kontakt: hamar@phil.muni.cz

Csaba Szaló působí na Katedře sociologie Fakulty sociálních studií Masarykovy univerzity v Brně. Zabývá se kulturní sociologií. Jeho výzkumné aktivity se zaměřují na proces kulturní asimilace a sociální konstrukce identit. Je autorem knihy Transnacionální migrace: Proměny identit, hranic a védění o nich (Brno: CDK 2007).

Kontakt: szalo@fss.muni.cz 